\title{
The Effect of Myco-Biocontrol Based Formulates on Yield, Physiology and Secondary Products of Organically Grown Basil
}

\author{
Gabriel-Ciprian Teliban ${ }^{1}$, Marian Burducea ${ }^{1,2} \oplus$, Valtcho D. Zheljazkov ${ }^{3}{ }^{(D}$, Ivayla Dincheva ${ }^{4}(\mathbb{D}$, \\ Ilian Badjakov ${ }^{4}\left(\mathbb{D}\right.$, Neculai Munteanu ${ }^{1}$, Gabriela Mihalache ${ }^{1,2}$, Alexandru Cojocaru ${ }^{1} \mathbb{D}$, Lorena-Diana Popa ${ }^{5}$ \\ and Vasile Stoleru ${ }^{1, *(\mathbb{D})}$
}

Citation: Teliban, G.-C.; Burducea, M.; Zheljazkov, V.D.; Dincheva, I.; Badjakov, I.; Munteanu, N.; Mihalache, G.; Cojocaru, A.; Popa, L.-D.; Stoleru, V. The Effect of Myco-Biocontrol Based Formulates on Yield, Physiology and Secondary Products of Organically Grown Basil. Agriculture 2021, 11, 180. https:// doi.org/10.3390/agriculture11020180

Academic Editors: Mumtaz Cheema, Gianluca Caruso and László Baranyai

Received: 30 January 2021

Accepted: 19 February 2021

Published: 23 February 2021

Publisher's Note: MDPI stays neutral with regard to jurisdictional claims in published maps and institutional affiliations.

Copyright: (c) 2021 by the authors Licensee MDPI, Basel, Switzerland. This article is an open access article distributed under the terms and conditions of the Creative Commons Attribution (CC BY) license (https:/ / creativecommons.org/licenses/by/ $4.0 /)$.
1 Department of Horticulture, "Ion Ionescu de la Brad" University of Agricultural Sciences and Veterinary Medicine, 3 M. Sadoveanu, 700440 Iasi, Romania; gabrielteliban@uaiasi.ro (G.-C.T.); marian.burducea@yahoo.com (M.B.); nmunte@uaiasi.ro (N.M.); gabriela.mihalache@uaic.ro (G.M.); acojocaru@uaiasi.ro (A.C.)

2 Research and Development Station for Aquaculture and Aquatic Ecology, Integrated Center of Environmental Science Studies in the North East Region, "Alexandru Ioan Cuza" University, Carol I Blvd, 700506 Iasi, Romania

3 Department of Crop and Soil Science, Oregon State University, 3050 SW Campus Way, 109 Crop Science Building, Corvallis, OR 97331, USA; valtcho.jeliazkov@oregonstate.edu

4 Plant Genetic Research Group, AgroBioInstitute, Agricultural Academy, 8 Dragan Tsankov Blvd., 1164 Sofia, Bulgaria; ivadincheva@yahoo.com (I.D.); ibadjakov@gmail.com (I.B.)

5 Agricultural Research and Development Station, 377 Principala Street, 617415 Secuieni Neamt, Romania; dy.hemp420@gmail.com

* Correspondence: vstoleru@uaiasi.ro; Tel.: +40-332-421680

\begin{abstract}
The development of organic farming as a result of increasing consumer preference for organic food has led to the development and registration of new pest-control products for certified organic production. In this study, the effects of three biocontrol products containing spores and mycelium of Arthrobotrys oligospora-Artis ${ }^{\circledR}$, Beauveria bassiana-Bora ${ }^{\circledR}$, and Coniothyrium minitansÖko-ni ${ }^{\circledR}$ were tested on four basil (Ocimum basilicum L.) cultivars: 'Aromat de Buzau', 'Serafim', 'Macedon' and 'Cuisoare'. The application of Öko-ni ${ }^{\circledR}$ increased basil yields by $8 \%$ relative to Control. The application of Bora ${ }^{\circledR}$ increased chlorophyll content of basil leaves by $2 \%$ and the activity of photosynthesis by $66 \%$ relative to the Control. Basil essential oil (EO) content was increased by $18 \%$ with the application of Artis ${ }^{\circledR}$ and by $34 \%$ with the application of Bora ${ }^{\circledR}$ and Öko-ni ${ }^{\circledR}$, respectively. The content of phenolic compounds analyzed by HPLC varied; caffeic acid concentration was higher in the plants treated with Öko-ni ${ }^{\circledR}$, hyperoside, isoquercitrin and rutin concentrations were higher in those treated with Artis ${ }^{\circledR}$, while the quercitrin content was higher in Bora ${ }^{\circledR}$-treated plants. The two main EO constituents that were identified were linalool and methyl chavicol in 'Aromat de Buzau', linalool and eugenol in 'Serafim', neral and geranial in 'Macedon', also linalool and eugenol in 'Cuisoare'. The investigated myco-biocontrol products had positive effects on basil fresh biomass and $\mathrm{EO}$ content and also influenced the content of phenolic compounds.
\end{abstract}

Keywords: Ocimum basilicum L.; organic farming; biocontrol; yield; physiology; phenolic compounds; essential oils

\section{Introduction}

Basil (Ocimum basilicum L.) is one of the most widely organically grown species in the world [1]. Basil produces bioactive substances such as essential oil (EO) and phenolic compounds with great importance to drug, perfumery and food industries [2,3]. These substances, which are produced in the plant secondary metabolism pathways, have been shown to play a protective role against pests or UV radiation, and their concentration in plant biomass vary as a function of environmental factors such as drought or extreme 
temperatures [4,5]. Basil can be successfully grown both in the open field and in greenhouses. Both the cultivar and the growing conditions influence the synthesis of bioactive compounds. According to Zheljazkov et al. (2008), basil cultivars have a great variability of phenotype and chemotype. The European chemotype is characterized by a high content of linalool and methyl chavicol, Reunion chemotype has a rich content of methyl chavicol, tropical chemotypes have a rich methyl cinnamate content, while chemotypes grown in Eastern Europe, Russia, and many parts of Asia and North Africa have a high eugenol content [2]. Selection of appropriate genetic material and growth methods can lead to better production with desired aromatic and phenolic profiles [6-8]. Organic farming and organic food production have been expanding rapidly around the world. For example, certified organic land in the European Union (EU) has increased by 70\%, reaching 7.5\% (13.4 million hectares) of the total cultivated land in the last 10 years [9]. The sales of organic food and non-food products in the United States reached a record \$55.1 billion in 2019 [10]. Of these, $\$ 50.1$ billion were organic food sales and $\$ 5$ billion were organic non-food products. The growth rate for organic ( $4.6 \%$ for organic food and $9.2 \%$ for non-food sales) outperformed the overall U.S. food sales increase of $2 \%$ [10].

In the EU, organic farming is supported by the Common Agricultural Policy. The role of organic farming is to provide quality food while protecting the environment [11-15] Synthetic pesticides and fertilizers, GMO, antibiotics, synthetic growth hormones, artificial flavors, colors and preservation, sewage sludge and irradiation are not allowed in certified organic production. The EU has launched a new strategy entitled Farm to Fork which aims to increase organic crops production up to $25 \%$ by 2030 . It also proposes reducing by $50 \%$ the use of pesticides $[16,17]$ and dedicating $10 \%$ of the agricultural area to high-diversity landscapes, which facilitates alternatives to chemical pest control as required in organic farming [18].

Biological control products for pests and diseases management can be used in organic cropping systems, once they have been registered as such. These products are based on the ability of viruses, bacteria, fungi, nematodes or insects to biologically control crops parasites such as nematodes, insects or fungi [19]. This study focused on biological control products based on microorganisms with action on nematodes, insects and pathogenic fungi. For example, Arthrobotrys oligospora can be used as a nematicide, being a nematode-trapping fungus that lives mainly as saprophyte. This species enters nematodes by three-dimensional networks through processes of adhesion, penetration and immobilization. Currently, about 100 species of parasitic nematodes are known to reduce the crop growth and yields, and therefore, nematode control is economically important [20].

In terms of insect pest control in crops, good results have been obtained with entomopathogenic fungal species (EPF) Beauveria bassiana, Akanthomyces spp., Metarhizium anisopliae, and Mitosporic hypocrean fungi [21,22]. EPF species can target Lepidoptera, Coleoptera, Hemiptera, and Diptera [23]. For example, Zafar et al. [24] showed that Metarhizium anisopliae can kill up to $90 \%$ of the population of diamondback moth (Plutella xylostella), a pathogen that affects cabbage culture, by weakening the immune system of hosts through reduced synthesis of the antioxidant enzymes superoxide dismutase and phenoloxidase. Beauveria bassiana has been used successfully as a biological agent to control western flower thrips (Frankliniella occidentalis) and was efficient in plants such as impatiens and cucumbers $[25,26]$. Moreover, Beauveria bassiana has been shown to be effective in combating western flower thrips at different life stages [27].

Among the fungal diseases, Sclerotinia sp., a filamentous fungus that can infect about 400 species of crop plants, causes yield losses of up to 50\% [28]. Coniothyrium minitans is a sclerotial mycoparasite that has been reported as an effective biological control agent against Sclerotinia sclerotiorum in a number of crops including lettuce, celery, sunflower, bean, and oilseed rape [29].

Numerous studies have shown the effectiveness of biological control agents on investigated pathogens; however, there is insufficient information about their effect on crop physiology and the accumulation of plant primary and secondary metabolites. For exam- 
ple, some studies have shown that post-endophytic colonization with Metarhizium robertsii can stimulate plant growth by transfer insect-derived nitrogen to plants [30]. Another example of how biocontrol agents can stimulate physiological processes is Trichoderma spp., which significantly increased the rate of photosynthesis and stomatal conductance in rice, increased water holding capacity and therefore, enhanced drought stress resistance [31-33]. These positive effects biocontrol agents on plants can mitigate the negative consequences associated with the ban of synthetic pesticides and fertilizers in organic cropping systems. In this context, the objective of this study was to evaluate the effects of three biological control products based on microorganisms (Arthrobotrys oligospora, Beauveria bassiana, and Coniothyrium minitans) on biomass yields, physiology and the synthesis of phenolic compounds and EO in four organically grown basil varieties ('Aromat de Buzau', 'Serafim', 'Macedon' and 'Cuisoare').

\section{Materials and Methods}

\subsection{Biological Material and Experimental Site}

In this study, four cultivars of common basil (Ocimum basilicum L.) were used: 'Aromat de Buzau' (AB) — a cultivar with green leaves and white flowers; 'Serafim' (S) — a cultivar with red leaves and pink flowers; 'Macedon' (M) — a cultivar with green leaves, white flowers and lemon scent; and 'Cuisoare' (C) - a cultivar with green leaves, purple flowers and clove scent. All cultivars were obtained from Vegetable Research Development Station, Buzau.

The experiment was carried out on basil (Ocimum basilicum L.) grown in an open field in 2018 and 2019. The seeds were germinated in the greenhouse on April 16, and one month after germination (May 21) the plantlets were transplanted in the experimental field ("Vasile Adamachi" Research Farm of the University of Agricultural Sciences and Veterinary Medicine of Iasi, Romania). The distance between the plants was $15 \mathrm{~cm}$ in rows and $45 \mathrm{~cm}$ between the rows resulting in a density of 14.8 plants. $\mathrm{m}^{-2}$. The crop management practices carried out during the vegetation period were those recommended by the literature [5]. The plants were harvested at full flowering at the beginning of August. Weed control was conducted by removing weeds manually, while irrigation was done only when the amount of water available in the soil dropped below $80 \%$. The temperature, humidity and amount of precipitation during the experiment, in both research years, are presented in Table 1.

Table 1. The meteorological conditions during the study.

\begin{tabular}{ccccccc}
\hline Month & $\begin{array}{c}\text { Temperature of Air } \\
\left({ }^{\circ} \mathbf{C}\right)\end{array}$ & \multicolumn{2}{c}{$\begin{array}{c}\text { Humidity } \\
(\mathbf{\%})\end{array}$} & $\mathbf{2 0 1 9}$ & \multicolumn{2}{c}{$\begin{array}{c}\text { Precipitation } \\
(\mathbf{m m})\end{array}$} \\
\hline & $\mathbf{2 0 1 8}$ & $\mathbf{2 0 1 9}$ & $\mathbf{2 0 1 8}$ & $\mathbf{2 0 1 8}$ & $\mathbf{2 0 1 9}$ \\
\hline April & 15.3 & 10.7 & 60 & 66 & 6.4 & 6.9 \\
May & 18.9 & 16.6 & 61 & 77 & 10.9 & 74.9 \\
June & 21.3 & 22.7 & 72 & 59 & 161.9 & 8.4 \\
July & 21.9 & 22.0 & 77 & 67 & 136.4 & 3.8 \\
August & 23.0 & 22.1 & 67 & 67 & 5.6 & 35.1 \\
\hline
\end{tabular}

The soil at the experimental site was anthropic cambic chernozem with the following physico-chemical characteristics: $6 \%$ silt, $32 \%$ clay; pH 7.2; EC $495 \mu \mathrm{S} \cdot \mathrm{cm}^{-1} ; 2.86 \%$ humus; $2.8 \mathrm{~g} \cdot \mathrm{kg}^{-1} \mathrm{~N}, 32 \mathrm{mg} \cdot \mathrm{kg}^{-1}$ available $\mathrm{P}, 218 \mathrm{mg} \cdot \mathrm{kg}^{-1}$ available $\mathrm{K}, 4.1 \mathrm{~g} \cdot \mathrm{kg}^{-1} \mathrm{CaCO}_{3}$; C/N 5.93.

\subsection{Experimental Design}

In this study, the experimental protocol included 2 factors: (1) cultivar at four levels ('Aromat de Buzau' (AB), 'Serafim' (S), 'Macedon' (M), and 'Cuisoare' (C), and (2) three myco-biocontrol products (Artis ${ }^{\circledR}$, Bora $^{\circledR}$ and Öko-ni ${ }^{\circledR}$ ), and Control (untreated). A split plot design with three replicates was arranged for treatment distribution in the field, 
and each experimental unit covered a $4.05 \mathrm{~m}^{2}$ surface area that included 60 individual basil plants.

The organic myco-biocontrol formulates were purchased from Kwizda Agro, and all treatments were applied by spraying the soil 5 days before transplanting at a rate of $1.5 \mathrm{~kg} \cdot \mathrm{ha}^{-1}$.

According to the manufacturer, the products contained the spores and mycelium of three different fungi as follows: Artis ${ }^{\circledR}$ - Arthrobotrys oligospora AO1 (NCAIM 153/2012) strain $(5 \mathrm{~m} / \mathrm{m} \%), 5 \times 10^{5} \mathrm{CFU} \cdot \mathrm{g}^{-1}$; Bora ${ }^{\circledR}$-Beauveria bassiana BB1 (NCAIM 128/2010) strain $(5 \mathrm{~m} / \mathrm{m} \%), 1.5 \times 10^{7} \mathrm{CFU} \cdot \mathrm{g}^{-1}$ and Öko-ni ${ }^{\circledR}$ —Coniothyrium minitans $\mathrm{K} 1$ (NCAIM $51 / 2004)$ strain $(5 \mathrm{~m} / \mathrm{m} \%) 1.5 \times 10^{7} \mathrm{CFU} \cdot \mathrm{g}^{-1}$. The products are allowed to be used in organic agriculture to combat soil pests (nematodes, insects and fungi) but also to stimulate plant growth.

\subsection{Yield Determination}

Fresh biomass yield per hectare was determined by harvesting the plants at $5 \mathrm{~cm}$ aboveground and taking the fresh weight with a Kern analytical balance with an error of $0.01 \mathrm{~g}$. The yields were calculated and presented as $\mathrm{t} \cdot \mathrm{ha}^{-1}$.

\subsection{Total Chlorophyll Content Determination}

The total chlorophyll content was measured with a non-destructive portable chlorophyll content meter (CCM-200 plus Opti-Sciences Chlorophyll Content Meter, ADC BioScientific Ltd., Global House, Geddings Road, Hoddesdon, Herts, EN11 0NT, UK), the readings being expressed as $\mathrm{CCI}$ units. The measurements were done one day before harvest in the time interval 9-10 AM. For each experimental variant, 9 readings from 15 leaves were performed.

\subsection{Photosynthesis Determination}

Photosynthesis ( $\mu \mathrm{mol} \mathrm{CO} \mathrm{CO}_{2} \mathrm{~s}^{-1}$ ), was measured with a portable compact system LCi (ADC Bioscientific UK Ltd., Global House, Geddings Road, Hoddesdon, Herts, EN11 ONT, UK), with a Broad Leaf Chamber, with an area of $6.4 \mathrm{~cm}^{2}$, between 9-10 AM. The measurements were performed the day before harvesting, from 9 to $10 \mathrm{AM}$.

\subsection{Phenolic Compounds Extraction and Chromatographic Separation}

Phenolic compounds were analyzed from a $5 \%(w / v)$ leaf extract in absolute methanol, with Agilent 1100 HPLC Series (Agilent, Technologies Inc., Santa Clara, CA, USA). The column used for separation was Zorbax SB-C18 $100 \times 3.0 \mathrm{~mm}$ i.d., $3.5 \mu \mathrm{m}$ particle. The temperature used for the detection of the studied compounds was $48^{\circ} \mathrm{C}$, and the working mode was UV. The mobile phase was a binary gradient of methanol and $0.1 \%$ acetic acid solution $(v / v)$. The elution started with a linear gradient, beginning with $5 \%$ methanol and ending at $42 \%$ methanol, for $35 \mathrm{~min}$; isocratic elution followed for the next $3 \mathrm{~min}$ with $42 \%$ methanol. The flow rate was $1 \mathrm{~mL} / \mathrm{min}$ and the injection volume was $5 \mu \mathrm{L}$. Quantitative determination of selected compounds (caffeic acid, hyperoside, isoquercitrin, rutin, and quercitrin) was performed using the external standard method. Five-point plot calibration curves in the range of $0.5-50 \mu \mathrm{g} \cdot \mathrm{mL}^{-1}$ with linearity $\mathrm{R}^{2}>0.999$ were used. The quantification limit for all compounds was $0.5 \mu \mathrm{g} \cdot \mathrm{mL}^{-1}$. Retention times were: caffeic acid $6.52 \mathrm{~min}$, hyperoside $19.32 \mathrm{~min}$, isoquercitrin $20.29 \mathrm{~min}$, rutin $20.76 \mathrm{~min}$, and quercitrin $23.64 \mathrm{~min}$. Standards of rutin and isoquercitrin were purchased from Sigma-Aldrich (St. Louis, MO, USA), while caffeic acid, hyperoside, and quercitrin, from Roth (Karlsruhe, Germany), with a purity $\geq 98.0 \%$. Methanol of HPLC analytical-grade and acetic acid of HPLC analytical-grade, were purchased from Merck (Darmstadt, Germany) [34].

\subsection{Essential Oil (EO) Extraction and Chromatographic Separation}

The EO from fresh basil herbage (leaves, stems, and flowers) was extracted by hydrodistillation from $50 \mathrm{~g}$ of material in a Clevenger type apparatus, using a ratio of $1 / 4$ 
plant material/water in $3 \mathrm{~L}$ flasks. The extraction lasted $3 \mathrm{~h}$ and the oil obtained $\left(\mathrm{mL} \mathrm{oil} \cdot \mathrm{g}^{-1}\right.$ of fresh weight) was expressed as \% fresh weight (f.w.).

The chemical composition of the EOs was determined by GC/FID-GC/MS. The system used was Agilent 5975C MSD coupled to Agilent 7890A GC (Agilent Technologies Inc., Santa Clara, CA, USA). The column $(30 \mathrm{~m}, 0.32 \mathrm{~mm}, 0.25 \mu \mathrm{m})$ used was Agilent J\&W HP-5MS, and the gas carrier $\left(1.0 \mathrm{~mL} \mathrm{~min}^{-1}\right)$ was helium (purity $\left.99.99 \%\right)$. The operating conditions were: oven temperature $60^{\circ} \mathrm{C}(3 \mathrm{~min}), 1^{\circ} \mathrm{C} \mathrm{min}^{-1}$ to $80^{\circ} \mathrm{C}(3 \mathrm{~min}) ; 5^{\circ} \mathrm{C} \mathrm{min}^{-1}$

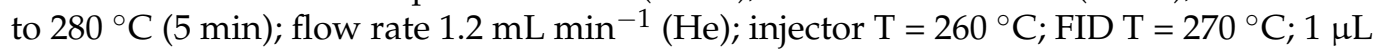
injection volume at split ratio $20: 1$. The mass spectrometry conditions were: ionization voltage $70 \mathrm{eV}$, ion source temperature $230{ }^{\circ} \mathrm{C}$, transfer line temperature $280{ }^{\circ} \mathrm{C}$, solvent delay $4.00 \mathrm{~min}$, and mass range: $50-500 \mathrm{Da}$. The MS was operated in scan mode. One (1) $\mu \mathrm{L}$ of EO was diluted in n-hexane $(10 \%, v / v)$ and injected into the GC/MS system. Triplicate injections were performed simultaneous using the same column and operational conditions in order to obtain the same elution order with GC/MS.

Compounds were identified by comparing mass spectra of compounds in sample with those from NIST 08 and Adams mass spectra libraries, by AMDIS (Automated Mass Spectral Deconvolution and Identification System), and by comparing literature and estimated Kovats (retention) indices. A mixture of homologous series of normal alkanes from $\mathrm{C}_{8}$ to $\mathrm{C}_{40}$ in hexane, under the same above-mentioned conditions, was used for determination. The percentage ratio of EOs components was computed by the normalization method of the GC/FID peak areas, and average values were taken into further consideration [35,36].

\subsection{Statistical Analysis}

The results were reported as means \pm standard errors of the two years' experiment (2018-2019). Descriptive statistics and Shapiro-Wilk test were performed to assess the normality. The ANOVA test was used to highlight the statistical significance of the differences. Where the differences were significant, the Tukey $(p<0.05)$ multiple comparison test was used. The software used was SPSS v21 (IBM Corp, Armonk, NY, USA).

\section{Results}

The influence of cultivar and myco-biocontrol product on fresh yield, EO content and some physiological parameters (content of assimilatory pigments and photosynthesis rate) is presented in Table 2. The highest fresh herbage yield was obtained for 'Cuisoare' $(+19 \%)$ followed by 'Macedon' $(+14 \%)$ as compared to the average yield for the cultivars, while the lowest herbage yields were obtained for 'Serafim' $(-18 \%)$. In terms of EO content, 'Macedon' produced the highest amount $(+44 \%)$, while 'Serafim' produced the lowest $(-20 \%)$ compared to the average oil content for cultivars. Assimilatory pigment content was almost double in 'Serafim' compared to the other cultivars, while photosynthesis was almost twice as high in 'Aromat de Buzau' and 'Serafim' compared to that of 'Macedon' and 'Cuisoare'.

The application of biocontrol products Öko-ni ${ }^{\circledR}$, Artis $^{\circledR}$ and Bora ${ }^{\circledR}$ increased basil fresh herbage yields compared to the control. A stimulating effect was also observed on the EO accumulation, with increases of $34 \%$ in Öko-ni ${ }^{\circledR}$ and Bora ${ }^{\circledR}$ and $18 \%$ in Artis ${ }^{\circledR}$. The content of assimilatory pigments increased only in Bora ${ }^{\circledR}(2.5 \%)$, corresponding to the largest increase in the rate of photosynthesis $(66 \%)$ compared with the control.

The interaction effects of cultivar and the biocontrol products are presented in Figures 1-4. In terms of fresh yield (Figure 1), the highest value was recorded for the 'Cuisoare' treated with Öko-ni ${ }^{\circledR}\left(\mathrm{C} \times\right.$ Öko-ni $\left.^{\circledR}\right)$, while the EO content was highest in 'Macedon' treated with Bora ${ }^{\circledR}$ and Öko-ni ${ }^{\circledR}\left(\mathrm{M} \times\right.$ Bora $^{\circledR}$ and $\mathrm{M} \times$ Öko-ni $\left.^{\circledR}\right)$ (Figure 2). In terms of physiological parameters, the combination of the two factors showed that the highest values of assimilatory pigment contents were recorded in $\mathrm{S} \times$ Control and $\mathrm{S} \times$ Bora $^{\circledR}$ (Figure 3), and photosynthesis was significantly higher in $S \times \operatorname{Artis}^{\circledR}$ (Figure 4). 
Table 2. Influence of cultivar and myco-biocontrol formulates on fresh yield, essential oil (EO) content, assimilatory pigments and photosynthesis rate of basil.

\begin{tabular}{|c|c|c|c|c|}
\hline Treatment & $\begin{array}{l}\text { Fresh Yield } \\
\quad\left(t \cdot h a^{-1}\right)\end{array}$ & $\begin{array}{c}\text { Essential Oil Content } \\
(\%)\end{array}$ & $\begin{array}{l}\text { Assimilatory Pigments } \\
\text { (CCI) }\end{array}$ & $\begin{array}{l}\text { Photosynthesis Rate } \\
\quad\left(\mu \mathrm{mols} \cdot \mathrm{m}^{-2} \cdot \mathrm{s}^{-1}\right)\end{array}$ \\
\hline \multicolumn{5}{|c|}{ Cultivar } \\
\hline 'Aromat de Buzau' & $25.41 \pm 0.33 c$ & $1.20 \pm 0.02 b$ & $11.01 \pm 0.18 \mathrm{~d}$ & $4.77 \pm 0.12 \mathrm{a}$ \\
\hline 'Serafim' & $24.31 \pm 0.12 \mathrm{~d}$ & $1.05 \pm 0.06 c$ & $25.21 \pm 0.59 \mathrm{a}$ & $3.70 \pm 0.19 b$ \\
\hline ‘Macedon' & $34.14 \pm 0.52 \mathrm{~b}$ & $1.90 \pm 0.14 \mathrm{a}$ & $16.34 \pm 0.45 b$ & $1.27 \pm 0.04 \mathrm{~d}$ \\
\hline ‘Cuisoare' & $35.82 \pm 0.59 a$ & $1.12 \pm 0.02 \mathrm{c}$ & $14.55 \pm 0.35 c$ & $1.82 \pm 0.07 c$ \\
\hline \multicolumn{5}{|c|}{ Myco-biocontrol formulates } \\
\hline Control & $28.36 \pm 1.24 c$ & $1.08 \pm 0.04 c$ & $17.26 \pm 0.33 \mathrm{ab}$ & $2.09 \pm 0.08 b$ \\
\hline Artis $^{\circledR}$ & $30.42 \pm 1.38 \mathrm{~b}$ & $1.28 \pm 0.10 \mathrm{~b}$ & $16.30 \pm 0.34 \mathrm{ab}$ & $3.40 \pm 0.23 \mathrm{a}$ \\
\hline Bora $^{\circledR}$ & $30.09 \pm 1.49 \mathrm{~b}$ & $1.45 \pm 0.16 \mathrm{a}$ & $17.70 \pm 0.43 \mathrm{a}$ & $3.47 \pm 0.18 \mathrm{a}$ \\
\hline Öko-ni ${ }^{\circledR}$ & $30.81 \pm 1.86 \mathrm{a}$ & $1.45 \pm 0.14 \mathrm{a}$ & $15.85 \pm 0.33 b$ & $2.60 \pm 0.17 b$ \\
\hline
\end{tabular}

Values with the same lower-case letters are not statistically different at $p<0.05$ according to Tukey's test.

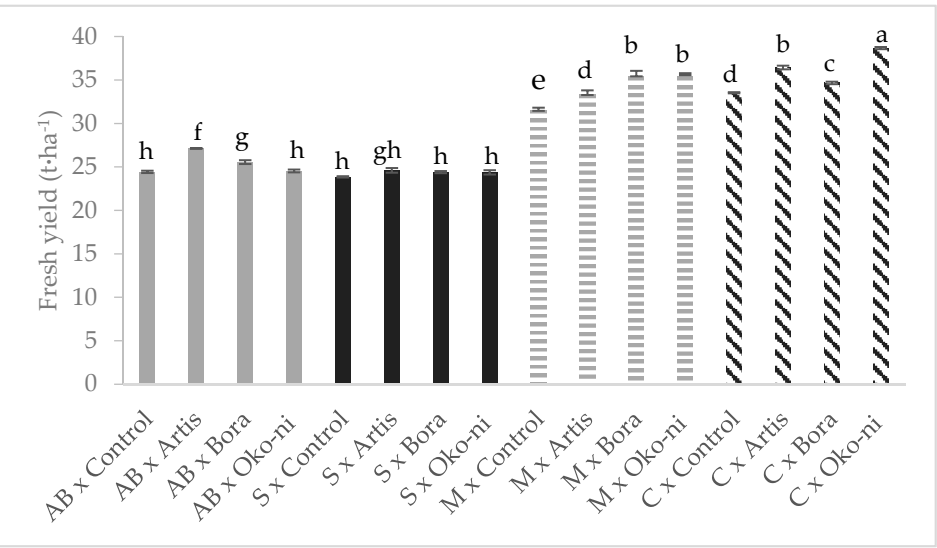

Figure 1. Interaction effects of cultivar and myco-biocontrol product on fresh yield of basil. Values with the same lower-case letters are not statistically different at $p<0.05$ according to Tukey's test. AB-'Aromat de Buzau'; S-'Serafim'; M-'Macedon'; C-'Cuisoare'.

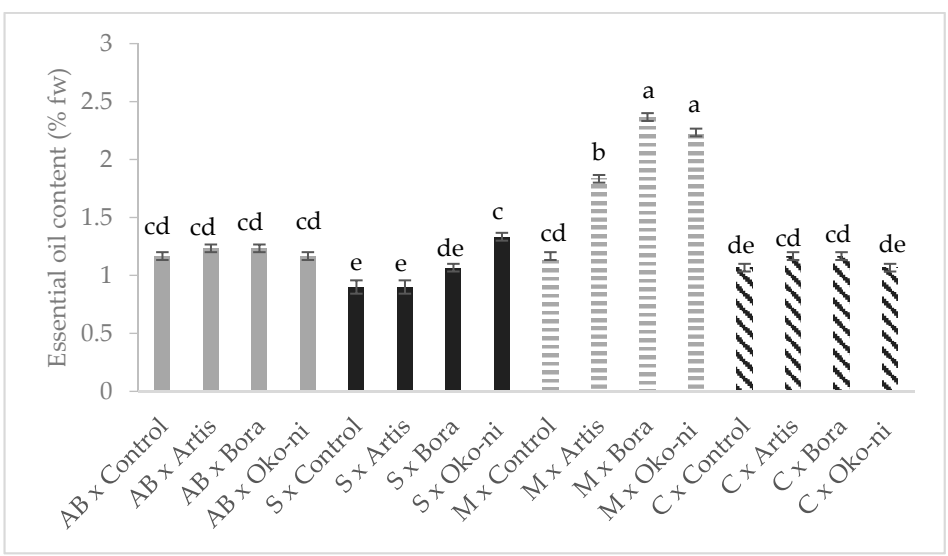

Figure 2. Interaction effects of cultivar and myco-biocontrol formulate on essential oil content of basil. Values with the same lower-case letters are not statistically different at $p<0.05$ according to Tukey's test. AB-'Aromat de Buzau'; S-'Serafim'; M-'Macedon'; C-'Cuisoare' 


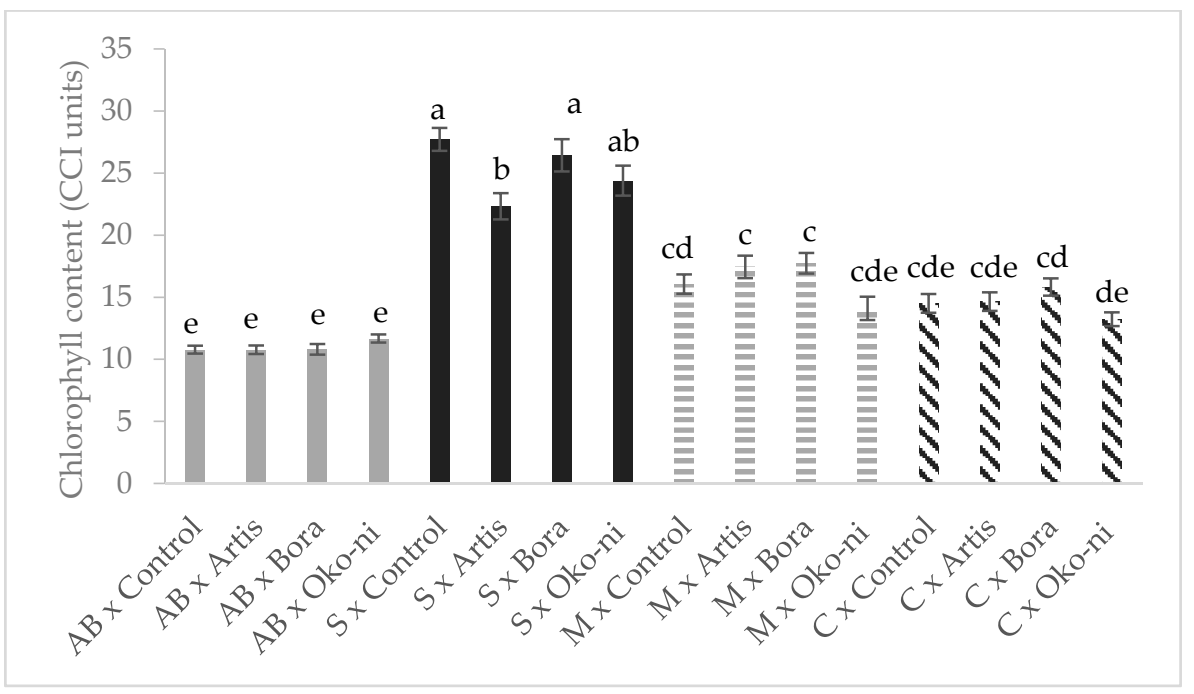

Figure 3. Interaction effects of cultivar and myco-biocontrol formulate on assimilatory pigments of basil. Values with the same lower-case letters are not statistically different at $p<0.05$ according to Tukey's test. AB-'Aromat de Buzau'; S—'Serafim'; M-'Macedon'; C-'Cuisoare'.

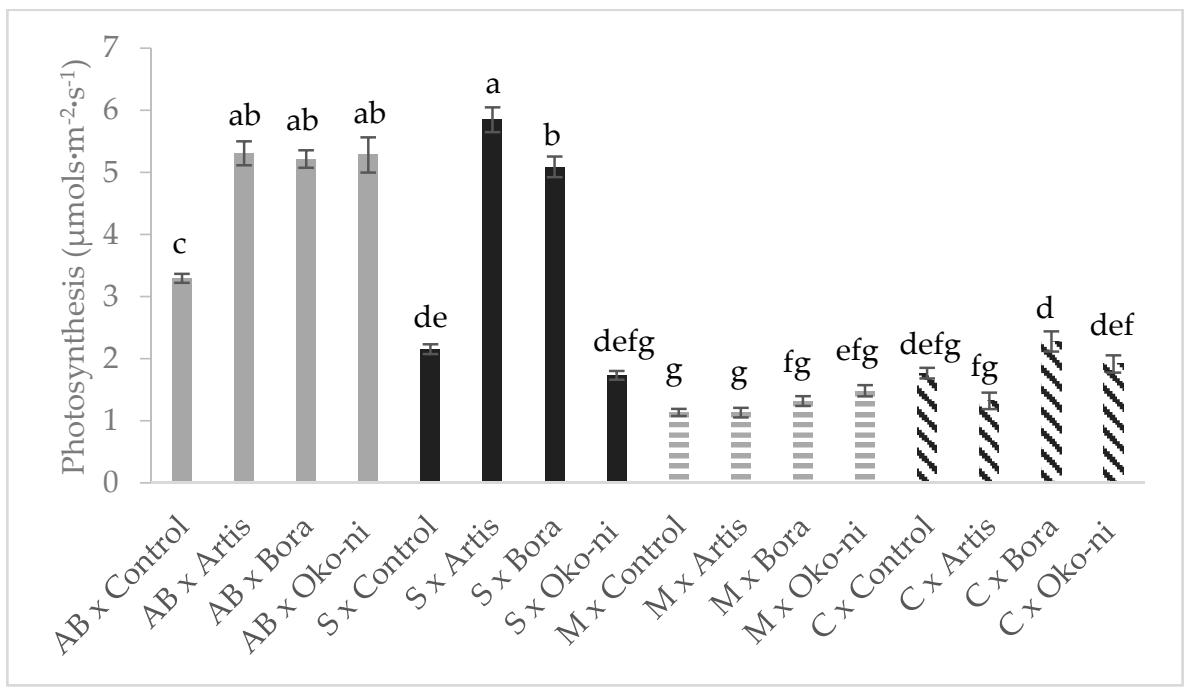

Figure 4. Interaction effects of cultivar and myco-biocontrol formulates on photosynthesis of basil. Values with the same lower-case letters are not statistically different at $p<0.05$ according to Tukey's test. AB-'Aromat de Buzau'; S-'Serafim'; M-'Macedon'; C—'Cuisoare'.

In this study, five phenolic compounds were selected for quantification, based on previous studies: caffeic acid, hyperoside, isoquercitrin, rutin and quercitrin. The results of the influence of the cultivar and myco-biocontrol formulates on the synthesis of phenolic compounds are shown in Table 3. Hyperoside was identified only in cv. 'Macedon'. Moreover, isoquercitrin concentration in this cultivar was the highest, three folds higher than in cv. 'Serafim'. The highest content of caffeic acid was obtained in 'Aromat de Buzau', while caffeic acid concentration in 'Cuisoare' was about three folds lower compared to the other cultivars. On the other hand, the highest content of rutin was identified in 'Cuisoare', while the highest content of quercitrin was identified in 'Aromat de Buzau'. 
Table 3. Influence of cultivar and myco-biocontrol formulates on phenolic compounds of basil.

\begin{tabular}{cccccc}
\hline Treatment & Caffeic Acid & Hyperoside & Isoquercitrin & Rutin & Quercitrin \\
\hline \multicolumn{7}{c}{ Cultivar } \\
\hline 'Aromat de Buzau' & $40.57 \pm 7.53 \mathrm{a}$ & $\operatorname{tr}$ & $324.22 \pm 7.52 \mathrm{c}$ & $468.18 \pm 8.81 \mathrm{~b}$ & $57.14 \pm 1.50 \mathrm{a}$ \\
'Serafim' & $38.50 \pm 6.85 \mathrm{~b}$ & $\operatorname{tr}$ & $122.44 \pm 9.41 \mathrm{~d}$ & $227.35 \pm 19.55 \mathrm{c}$ & $21.77 \pm 0.99 \mathrm{~d}$ \\
'Macedon' & $33.78 \pm 5.98 \mathrm{c}$ & $83.04 \pm 8.30$ & $413.09 \pm 14.04 \mathrm{a}$ & $483.55 \pm 59.50 \mathrm{c}$ & $35.21 \pm 1.69 \mathrm{~b}$ \\
'Cuisoare' & $11.47 \pm 6.05 \mathrm{~d}$ & $\operatorname{tr}$ & $342.17 \pm 15.66 \mathrm{~b}$ & $1057.08 \pm 71.54 \mathrm{a}$ & $31.11 \pm 3.21 \mathrm{c}$ \\
\hline \multicolumn{7}{c}{ Myco-biocontrol formulates } \\
\hline Control & $\operatorname{tr}$ & $18.45 \pm 9.64 \mathrm{c}$ & $284.78 \pm 31.42 \mathrm{bc}$ & $506.48 \pm 83.75 \mathrm{c}$ & $32.70 \pm 4.02 \mathrm{~b}$ \\
Artis $^{\circledR}$ & $35.99 \pm 6.50 \mathrm{c}$ & $26.30 \pm 13.75 \mathrm{a}$ & $354.11 \pm 34.19 \mathrm{a}$ & $664.82 \pm 125.96 \mathrm{a}$ & $36.90 \pm 3.29 \mathrm{a}$ \\
Bora $^{\circledR}$ & $37.86 \pm 6.69 \mathrm{~b}$ & $22.78 \pm 11.90 \mathrm{~b}$ & $279.03 \pm 36.41 \mathrm{c}$ & $487.89 \pm 88.50 \mathrm{~d}$ & $37.15 \pm 3.96 \mathrm{a}$ \\
Öko-ni $^{\circledR}$ & $51.37 \pm 1.84 \mathrm{a}$ & $23.19 \pm 12.11 \mathrm{~b}$ & $291.31 \pm 33.18 \mathrm{~b}$ & $571.21 \pm 103.00 \mathrm{~b}$ & $36.82 \pm 5.50 \mathrm{a}$ \\
\hline
\end{tabular}

Values with the same lower-case letters are not statistically different at $p<0.05$ according to Tukey's test; tr-traces.

The highest concentration increases for hyperosides, isoquercitrin and rutins $(42 \%, 24 \%$ and $31 \%$, respectively, compared to the control) were observed in Artis ${ }^{\circledR}$. The application of Bora ${ }^{\circledR}$ increased the content of quercitrin. The application of Öko-ni ${ }^{\circledR}$ increased the caffeic acid content, with an increase of $42 \%$ compared to Artis ${ }^{\circledR}$ and $35 \%$ compared to Bora ${ }^{\circledR}$. In addition, in the same treatment, the content of hyperoside, isoquercitrin, rutin and quercitrin increased compared to Control by $25 \%, 2 \%, 12 \%$, and $12 \%$, respectively.

The EO composition of basil is presented in Tables 4-7. The chemical composition of the EO, in terms of both the number of compounds identified their composition and concentration, varied depending on the cultivar and the treatment applied. Thirty (30) compounds were identified in the EO of 'Aromat de Buzau'. Among the main constituents, $\beta$-linalool, methyl chavicol, $\beta$-elemene, germacrene $D$, cis-muurol-5-en- $4 \alpha$-ol, and epi- $\alpha$-cadinol represented $86 \%$ of the total area under the curve (Table 4 ). Furthermore, 30 compounds were identified in the EO of 'Serafim', with main constituents Eucalyptol (1,8-Cineole), $\beta$-linalool, eugenol, $\beta$-elemene, germacrene $\mathrm{D}$, and epi- $\alpha$-cadinol representing $82 \%$ of the total oil (Table 5). Twenty-six (26) compounds were identified in the EO of the 'Macedon', the main ones being $\beta$-linalool, nerol, neral, geranial, $\beta$-caryophyllene, and (E) $-\gamma$-bisabolene, representing $80 \%$ of the total (Table 6). Thirty-six (36) compounds were identified in the EO of 'Cuisoare', the main constituents being $\beta$-linalool, eugenol, $\beta$-elemene, $\alpha$-transbergamotene, germacrene $\mathrm{D}$, and epi- $\alpha$-cadinol, representing $80 \%$ of the total oil (Table 7 ).

Table 4. Influence of myco-biocontrol formulates on essential oil composition of 'Aromat de Buzau'.

\begin{tabular}{|c|c|c|c|c|c|c|c|c|}
\hline No & Name & Class & $\mathbf{R I}_{\text {calc }}$ & $\mathbf{R I}_{\text {lit }}$ & Control & Artis $^{\circledR}$ & Bora $^{\circledR}$ & Öko-ni ${ }^{\circledR}$ \\
\hline 1 & Eucalyptol (1,8-Cineole) & Bicyclic monoterpenoids & 1031 & 1030 & 0.19 & 0.55 & 0.38 & 0.26 \\
\hline 2 & cis- $\beta$-Ocimene & Acyclic monoterpenes & 1040 & 1037 & 0.12 & 0.15 & 0.17 & $\operatorname{tr}$ \\
\hline 3 & $\beta$-Linalool & Acyclic monoterpenoids & 1095 & 1096 & 18.49 & 21.37 & 23.05 & 20.39 \\
\hline 4 & cis- $\beta$-Thujone & Bicyclic monoterpenoids & 1101 & 1102 & 0.18 & 0.20 & 0.16 & 0.20 \\
\hline 5 & trans- $\beta$-Thujone & Bicyclic monoterpenoids & 1112 & 1114 & 0.11 & 0.11 & 0.08 & 0.12 \\
\hline 6 & (Z)-Epoxy-ocimene & Monocyclic monoterpenoids & 1128 & 1132 & 0.12 & 0.16 & 0.24 & 0.18 \\
\hline 7 & Camphor & Bicyclic monoterpenoids & 1141 & 1145 & 0.70 & 0.79 & 0.80 & 0.90 \\
\hline 8 & Methyl chavicol & Phenolic monoterpenoids & 1195 & 1196 & 47.14 & 49.49 & 49.11 & 45.80 \\
\hline 9 & Bornyl acetate & Bicyclic monoterpenoids & 1284 & 1285 & tr & 0.31 & 0.22 & 0.36 \\
\hline 10 & trans-Linalool oxide acetate & Acyclic monoterpenoids & 1287 & 1288 & 0.91 & 0.62 & 0.67 & 0.78 \\
\hline 11 & Neryl acetate & Acyclic monoterpenoids & 1359 & 1361 & $\operatorname{tr}$ & $\operatorname{tr}$ & 0.35 & 0.18 \\
\hline 12 & Geranyl acetate & Acyclic monoterpenoids & 1379 & 1381 & 0.19 & $\operatorname{tr}$ & $\operatorname{tr}$ & $\operatorname{tr}$ \\
\hline 13 & $\beta$-Elemene & Monocyclic sesquiterpenes & 1389 & 1390 & 4.47 & 3.74 & 3.66 & 3.26 \\
\hline 14 & Methyl eugenol & Phenolic monoterpenoids & 1402 & 1403 & 0.78 & 0.62 & 0.46 & 0.89 \\
\hline 15 & $\beta$-Caryophyllene & Bicyclic sesquiterpenes & 1417 & 1419 & 0.68 & 0.48 & 0.53 & 0.61 \\
\hline 16 & $\alpha$-Guaiene & Bicyclic sesquiterpenes & 1436 & 1439 & 0.86 & 0.75 & 0.77 & 0.74 \\
\hline
\end{tabular}


Table 4. Cont.

\begin{tabular}{|c|c|c|c|c|c|c|c|c|}
\hline No & Name & Class & $\mathbf{R I}_{\text {calc }}$ & $\mathbf{R I}_{\text {lit }}$ & Control & Artis $^{\circledR}$ & Bora $^{\circledR}$ & Öko-ni ${ }^{\circledR}$ \\
\hline 17 & cis-Muurola-3,5-diene & Bicyclic sesquiterpenes & 1448 & 1450 & 0.10 & $\operatorname{tr}$ & 0.17 & $\operatorname{tr}$ \\
\hline 18 & trans-Muurola-3,5-diene & Bicyclic sesquiterpenes & 1451 & 1453 & 0.16 & $\operatorname{tr}$ & 0.14 & $\operatorname{tr}$ \\
\hline 19 & Humulene ( $\alpha$-Caryophyllene) & Monocyclic sesquiterpenes & 1454 & 1454 & 0.46 & 0.45 & 0.39 & 0.43 \\
\hline 20 & trans-Muurola-4(14),5-diene & Bicyclic sesquiterpenes & 1465 & 1466 & 0.32 & 0.25 & 0.25 & 0.26 \\
\hline 21 & Germacrene D & Monocyclic sesquiterpenes & 1481 & 1481 & 4.10 & 3.37 & 2.36 & 3.82 \\
\hline 22 & Bicyclogermacrene & Bicyclic sesquiterpenes & 1500 & 1501 & 0.72 & 0.48 & 0.49 & 0.50 \\
\hline 23 & $\alpha$-Bulnesene & Bicyclic sesquiterpenes & 1510 & 1509 & 1.72 & 1.39 & 1.30 & 1.56 \\
\hline 24 & $\gamma$-Cadinene & Bicyclic sesquiterpenes & 1513 & 1513 & 2.08 & 1.52 & 1.85 & 1.81 \\
\hline 25 & cis-Muurol-5-en- $4 \beta$-ol & Bicyclic sesquiterpenoids & 1551 & 1552 & 0.25 & 0.16 & 0.18 & 0.23 \\
\hline 26 & Elemicin & Phenolic monoterpenoids & 1155 & 1557 & 1.13 & 0.82 & 0.76 & 1.26 \\
\hline 27 & cis-Muurol-5-en- $4 \alpha$-ol & Bicyclic sesquiterpenoids & 1559 & 1561 & 8.86 & 5.37 & 5.27 & 9.10 \\
\hline 28 & 1,10-di-epi-Cubenol & Bicyclic sesquiterpenoids & 1618 & 1619 & 0.33 & 0.37 & 0.69 & 0.31 \\
\hline 29 & 1-epi-Cubenol & Bicyclic sesquiterpenoids & 1627 & 1628 & 0.78 & 0.88 & 0.72 & 0.89 \\
\hline \multirow[t]{10}{*}{30} & epi- $\alpha$-Cadinol & Bicyclic sesquiterpenoids & 1638 & 1640 & 3.07 & 4.61 & 3.80 & 4.17 \\
\hline & & & & & \multicolumn{4}{|c|}{$\operatorname{tr} \geq 0.03$} \\
\hline & & Acyclic monoterpenes & & & 0.12 & 0.15 & 0.17 & $\operatorname{tr}$ \\
\hline & & Acyclic monoterpenoids & & & 19.58 & 21.99 & 24.06 & 21.35 \\
\hline & & Monocyclic monoterpenoids & & & 0.12 & 0.16 & 0.24 & 0.18 \\
\hline & & Bicyclic monoterpenoids & & & 1.17 & 1.95 & 1.63 & 1.84 \\
\hline & & Phenolic monoterpenoids & & & 49.05 & 50.92 & 50.33 & 47.95 \\
\hline & & Monocyclic sesquiterpenes & & & 9.03 & 7.56 & 6.42 & 7.51 \\
\hline & & Bicyclic sesquiterpenes & & & 6.64 & 4.88 & 5.50 & 5.46 \\
\hline & & Bicyclic sesquiterpenoids & & & 13.29 & 11.39 & 10.66 & 14.71 \\
\hline
\end{tabular}

RIcalc—calculated Kovats index; RIlit—Kovats Index by literature data [36]; tr—traces.

Table 5. Influence of myco-biocontrol formulates on essential oil composition of 'Serafim'.

\begin{tabular}{|c|c|c|c|c|c|c|c|c|}
\hline No & Name & Class & $\mathbf{R I}_{\text {calc }}$ & $\mathbf{R I}_{\text {lit }}$ & Control & Artis $^{\circledR}$ & Bora $^{\circledR}$ & 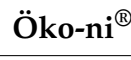 \\
\hline 1 & $\alpha$-Pinene & Bicyclic monoterpenes & 932 & 939 & $\operatorname{tr}$ & 0.08 & 0.06 & 0.10 \\
\hline 2 & Sabinene & Bicyclic monoterpenes & 969 & 974 & 0.09 & 0.11 & 0.17 & 0.21 \\
\hline 3 & $\beta$-Myrcene & Acyclic monoterpenes & 988 & 990 & 0.16 & 0.18 & $\operatorname{tr}$ & 0.11 \\
\hline 4 & Limonene & Monocyclic monoterpenes & 1024 & 1028 & 0.13 & 0.15 & 0.17 & 0.17 \\
\hline 5 & Eucalyptol (1,8-Cineole) & Bicyclic monoterpenoids & 1031 & 1030 & 3.31 & 4.04 & 3.75 & 3.70 \\
\hline 6 & cis- $\beta$-Ocimene & Acyclic monoterpenes & 1041 & 1037 & $\operatorname{tr}$ & $\operatorname{tr}$ & 0.16 & 0.16 \\
\hline 7 & Fenchone & Bicyclic monoterpenoids & 1083 & 1085 & 0.23 & 0.24 & 0.24 & 0.24 \\
\hline 8 & Terpinolene & Monocyclic monoterpenes & 1086 & 1088 & 0.16 & 0.16 & 0.15 & 0.15 \\
\hline 9 & $\beta$-Linalool & Acyclic monoterpenoids & 1095 & 1096 & 52.74 & 54.12 & 50.77 & 51.14 \\
\hline 10 & Camphor & Bicyclic monoterpenoids & 1141 & 1145 & 1.10 & 1.25 & 1.16 & 1.15 \\
\hline 11 & $\alpha$-Terpineol & Monocyclic monoterpenoids & 1188 & 1188 & 1.13 & $\operatorname{tr}$ & 1.23 & 1.22 \\
\hline 12 & endo-Fenchyl acetate & Bicyclic monoterpenoids & 1220 & 1221 & 0.24 & 0.30 & 0.37 & 0.37 \\
\hline 13 & cis-Carveol & Monocyclic monoterpenoids & 1229 & 1229 & 0.23 & 0.20 & 0.23 & 0.22 \\
\hline 14 & Geranial & Acyclic monoterpenoids & 1266 & 1267 & 0.31 & 0.28 & 0.31 & 0.31 \\
\hline 15 & Bornyl acetate & Bicyclic monoterpenoids & 1254 & 1285 & 0.45 & 0.36 & 0.53 & 0.52 \\
\hline 16 & Eugenol & Phenolic monoterpenoids & 1356 & 1358 & 8.96 & 9.12 & 10.22 & 10.70 \\
\hline 17 & $\alpha$-Copaene & Tricyclic sesquiterpenes & 1375 & 1376 & 0.19 & 0.20 & 0.20 & 0.19 \\
\hline 18 & $\beta$-Elemene & Monocyclic sesquiterpenes & 1389 & 1390 & 7.44 & 6.27 & 6.41 & 6.33 \\
\hline 19 & Methyl eugenol & Phenolic monoterpenoids & 1403 & 1403 & 0.32 & 0.30 & 0.41 & 0.41 \\
\hline 20 & $\beta$-Caryophyllene & Bicyclic sesquiterpenes & 1417 & 1419 & 1.32 & 1.48 & 1.59 & 1.57 \\
\hline 21 & $\alpha$-trans-Bergamotene & Bicyclic sesquiterpenes & 1433 & 1434 & 1.91 & 2.00 & 1.09 & 1.08 \\
\hline 22 & $\alpha$-Guaiene & Bicyclic sesquiterpenes & 1436 & 1439 & 1.68 & 1.46 & 1.53 & 1.50 \\
\hline 23 & Humulene ( $\alpha$-Caryophyllene) & Monocyclic sesquiterpenes & 1454 & 1454 & 0.79 & 0.69 & 0.71 & 0.70 \\
\hline 24 & Germacrene D & Monocyclic sesquiterpenes & 1481 & 1481 & 5.56 & 5.30 & 5.84 & 5.77 \\
\hline 25 & $\beta$-Selinene & Bicyclic sesquiterpenes & 1489 & 1490 & 0.40 & 0.31 & 0.27 & 0.27 \\
\hline 26 & Bicyclogermacrene & Bicyclic sesquiterpenes & 1500 & 1501 & $\operatorname{tr}$ & 0.38 & 0.49 & 0.57 \\
\hline 27 & $\alpha$-Bulnesene & Bicyclic sesquiterpenes & 1509 & 1509 & 3.21 & 2.77 & 2.87 & 2.83 \\
\hline 28 & $\gamma$-Cadinene & Bicyclic sesquiterpenes & 1513 & 1513 & 1.54 & 1.44 & 1.58 & 1.56 \\
\hline
\end{tabular}


Table 5. Cont.

\begin{tabular}{|c|c|c|c|c|c|c|c|c|}
\hline No & Name & Class & $\mathbf{R I}_{\text {calc }}$ & $\mathrm{RI}_{\text {lit }}$ & Control & Artis $^{\circledR}$ & Bora $^{\circledR}$ & Öko-ni ${ }^{\circledR}$ \\
\hline 29 & 1,10-di-epi-Cubenol & Bicyclic sesquiterpenoids & 1618 & 1628 & 0.62 & 0.54 & 0.65 & 0.64 \\
\hline \multirow[t]{13}{*}{30} & epi- $\alpha$-Cadinol & Bicyclic sesquiterpenoids & 1638 & 1640 & 4.78 & 4.24 & 4.79 & 4.73 \\
\hline & & & & & \multicolumn{4}{|c|}{$\operatorname{tr} \geq 0.03$} \\
\hline & & Acyclic monoterpenes & & & 0.16 & 0.18 & 0.16 & 0.27 \\
\hline & & Acyclic monoterpenoids & & & 53.04 & 54.40 & 51.08 & 51.45 \\
\hline & & Monocyclic monoterpenes & & & 0.29 & 0.31 & 0.32 & 0.32 \\
\hline & & Monocyclic monoterpenoids & & & 1.36 & 0.20 & 1.46 & 1.44 \\
\hline & & Bicyclic monoterpenes & & & 0.09 & 0.19 & 0.23 & 0.30 \\
\hline & & Bicyclic monoterpenoids & & & 5.32 & 6.18 & 6.05 & 5.97 \\
\hline & & Phenolic monoterpenoids & & & 9.28 & 9.41 & 10.64 & 11.10 \\
\hline & & Monocyclic sesquiterpenes & & & 13.80 & 12.26 & 12.97 & 12.81 \\
\hline & & Bicyclic sesquiterpenes & & & 10.06 & 9.84 & 9.41 & 9.37 \\
\hline & & Bicyclic sesquiterpenoids & & & 5.40 & 4.78 & 5.44 & 5.37 \\
\hline & & Tricyclic sesquiterpenes & & & 0.19 & 0.20 & 0.20 & 0.19 \\
\hline
\end{tabular}

RIcalc—calculated Kovats index; RIlit—Kovats Index by literature data [36]; tr—-traces.

Table 6. Influence of myco-biocontrol formulates on essential oil composition of 'Macedon'.

\begin{tabular}{|c|c|c|c|c|c|c|c|c|}
\hline No & Name & Class & $\mathbf{R I}_{\text {calc }}$ & $\mathbf{R I}_{\text {lit }}$ & Control & Artis $^{\circledR}$ & Bora $^{\circledR}$ & Öko-ni ${ }^{\circledR}$ \\
\hline 1 & cis- $\beta$-Ocimene & Acyclic monoterpenes & 1041 & 1037 & 0.41 & 0.31 & 0.52 & 0.37 \\
\hline 2 & $\beta$-Linalool & Acyclic monoterpenoids & 1095 & 1096 & 3.73 & 0.94 & 1.51 & 1.60 \\
\hline 3 & cis- $\beta$-Thujone & Bicyclic monoterpenoids & 1101 & 1102 & 0.56 & $\operatorname{tr}$ & $\operatorname{tr}$ & $\operatorname{tr}$ \\
\hline 4 & trans- $\beta$-Thujone & Bicyclic monoterpenoids & 1112 & 1114 & 0.22 & $\operatorname{tr}$ & $\operatorname{tr}$ & $\operatorname{tr}$ \\
\hline 5 & Camphor & Bicyclic monoterpenoids & 1141 & 1145 & 0.54 & $\operatorname{tr}$ & $\operatorname{tr}$ & $\operatorname{tr}$ \\
\hline 6 & (Z)-Isocitral & Acyclic monoterpenoids & 1163 & 1164 & 1.04 & 1.50 & 1.18 & 1.19 \\
\hline 7 & (E)- Isocitral & Acyclic monoterpenoids & 1179 & 1180 & 1.40 & 1.59 & 1.52 & 1.55 \\
\hline 8 & Methyl chavicol & Phenolic monoterpenoids & 1195 & 1196 & 1.70 & 0.63 & 0.92 & 1.07 \\
\hline 9 & Nerol & Acyclic monoterpenoids & 1227 & 1229 & 6.82 & 9.27 & 7.95 & 6.10 \\
\hline 10 & Neral & Acyclic monoterpenoids & 1235 & 1238 & 22.56 & 28.27 & 26.06 & 28.37 \\
\hline 11 & Geraniol & Acyclic monoterpenoids & 1251 & 1252 & 1.90 & 2.33 & 2.68 & 2.51 \\
\hline 12 & Geranial & Acyclic monoterpenoids & 1265 & 1267 & 30.90 & 34.05 & 31.02 & 34.34 \\
\hline 13 & Neryl acetate & Acyclic monoterpenoids & 1359 & 1361 & 0.93 & 1.10 & 0.95 & 0.88 \\
\hline 14 & Geranyl acetate & Acyclic monoterpenoids & 1379 & 1381 & 0.55 & $\operatorname{tr}$ & tr & $\operatorname{tr}$ \\
\hline 15 & $\alpha$-Copaene & Tricyclic sesquiterpenes & 1375 & 1376 & $\operatorname{tr}$ & 0.42 & 0.29 & 0.35 \\
\hline 16 & $\beta$-Elemene & Monocyclic sesquiterpenes & 1389 & 1390 & 0.47 & $\operatorname{tr}$ & $\operatorname{tr}$ & $\operatorname{tr}$ \\
\hline 17 & Methyl eugenol & Phenolic monoterpenoids & 1403 & 1403 & 1.17 & $\operatorname{tr}$ & 0.37 & 0.35 \\
\hline 18 & $\beta$-Caryophyllene & Bicyclic sesquiterpenes & 1417 & 1419 & 7.73 & 6.49 & 7.52 & 6.48 \\
\hline 19 & $\alpha$-trans-Bergamotene & Bicyclic sesquiterpenes & 1433 & 1434 & 1.58 & 1.74 & 2.01 & 1.94 \\
\hline 20 & Humulene ( $\alpha$-Caryophyllene) & Monocyclic sesquiterpenes & 1453 & 1454 & 1.29 & 1.07 & 1.18 & 1.10 \\
\hline 21 & (E)- $\beta$-Farnesene & Acyclic sesquiterpenes & 1455 & 1456 & 1.15 & 0.97 & 1.23 & 1.15 \\
\hline 22 & Sesquisabinene & Bicyclic sesquiterpenes & 1457 & 1459 & 0.16 & $\operatorname{tr}$ & 0.15 & $\operatorname{tr}$ \\
\hline 23 & Germacrene D & Monocyclic sesquiterpenes & 1481 & 1481 & 2.03 & 1.31 & 2.64 & 2.05 \\
\hline 24 & (Z)- $\gamma$-Bisabolene & Monocyclic sesquiterpenes & 1514 & 1515 & 0.40 & $\operatorname{tr}$ & 0.31 & $\operatorname{tr}$ \\
\hline 25 & (E)- $\gamma$-Bisabolene & Monocyclic sesquiterpenes & 1528 & 1530 & 8.97 & 6.28 & 7.99 & 6.75 \\
\hline \multirow[t]{11}{*}{26} & epi- $\alpha$-Cadinol & Bicyclic sesquiterpenoids & 1638 & 1640 & 0.44 & $\operatorname{tr}$ & tr & $\operatorname{tr}$ \\
\hline & & & & & \multicolumn{4}{|c|}{$\operatorname{tr} \geq 0.03$} \\
\hline & & Acyclic monoterpenes & & & 0.41 & 0.31 & 0.52 & 0.37 \\
\hline & & Acyclic monoterpenoids & & & 69.84 & 79.05 & 72.87 & 76.53 \\
\hline & & Bicyclic monoterpenoids & & & 1.33 & 0.00 & 0.00 & 0.00 \\
\hline & & Phenolic monoterpenoids & & & 2.88 & 0.63 & 1.29 & 1.42 \\
\hline & & Acyclic sesquiterpenes & & & 1.15 & 0.97 & 1.23 & 1.15 \\
\hline & & Monocyclic sesquiterpenes & & & 13.15 & 8.66 & 12.12 & 9.91 \\
\hline & & Bicyclic sesquiterpenes & & & 9.47 & 8.23 & 9.68 & 8.42 \\
\hline & & Bicyclic sesquiterpenoids & & & 0.44 & $\operatorname{tr}$ & $\operatorname{tr}$ & $\operatorname{tr}$ \\
\hline & & Tricyclic sesquiterpenes & & & $\operatorname{tr}$ & 0.42 & 0.29 & 0.35 \\
\hline
\end{tabular}


Table 7. Influence of myco-biocontrol formulates on essential oil composition of 'Cuisoare'.

\begin{tabular}{|c|c|c|c|c|c|c|c|c|}
\hline No & Name & Class & $\mathbf{R I}_{\text {calc }}$ & $\mathbf{R I}_{\text {lit }}$ & Control & Artis $^{\circledR}$ & Bora $^{\circledR}$ & Öko-ni ${ }^{\circledR}$ \\
\hline 1 & Sabinene & Bicyclic monoterpenes & 969 & 974 & $\operatorname{tr}$ & $\operatorname{tr}$ & $\operatorname{tr}$ & $\operatorname{tr}$ \\
\hline 2 & Sylvestrene & Monocyclic monoterpenes & 1026 & 1030 & 0.08 & $\operatorname{tr}$ & $\operatorname{tr}$ & 0.10 \\
\hline 3 & Eucalyptol (1,8-Cineole) & Bicyclic monoterpenoids & 1031 & 1030 & 2.74 & 1.54 & 1.56 & 1.44 \\
\hline 4 & cis- $\beta$-Ocimene & Acyclic monoterpenes & 1041 & 1037 & 0.45 & 0.20 & 0.21 & 0.40 \\
\hline 5 & Terpinolene & Monocyclic monoterpenes & 1086 & 1088 & $\operatorname{tr}$ & 0.00 & 0.00 & 0.00 \\
\hline 6 & $\beta$-Linalool & Acyclic monoterpenoids & 1095 & 1096 & 45.58 & 45.83 & 44.44 & 38.49 \\
\hline 7 & cis- $\beta$-Thujone & Bicyclic monoterpenoids & 1101 & 1102 & $\operatorname{tr}$ & $\operatorname{tr}$ & $\operatorname{tr}$ & $\operatorname{tr}$ \\
\hline 8 & trans- $\beta$-Thujone & Bicyclic monoterpenoids & 1112 & 1114 & $\operatorname{tr}$ & $\operatorname{tr}$ & $\operatorname{tr}$ & $\operatorname{tr}$ \\
\hline 9 & (Z)-Epoxy-ocimene & Monocyclic monoterpenoids & 1128 & 1132 & 0.52 & 0.37 & 0.38 & 0.35 \\
\hline 10 & Camphor & Bicyclic monoterpenoids & 1141 & 1145 & 0.28 & $\operatorname{tr}$ & 0.51 & 0.49 \\
\hline 11 & $\alpha$-Terpineol & Monocyclic monoterpenoids & 1188 & 1188 & 1.11 & $\operatorname{tr}$ & $\operatorname{tr}$ & $\operatorname{tr}$ \\
\hline 12 & Methyl chavicol & Phenolic monoterpenoids & 1195 & 1196 & $\operatorname{tr}$ & 1.60 & 1.62 & 1.43 \\
\hline 13 & cis-Carveol & Monocyclic monoterpenoids & 1229 & 1229 & 0.46 & 0.20 & 0.20 & 0.22 \\
\hline 14 & Geranial & Acyclic monoterpenoids & 1266 & 1267 & 0.58 & 0.26 & 0.26 & 0.30 \\
\hline 15 & Bornyl acetate & Bicyclic monoterpenoids & 1284 & 1285 & 1.55 & 1.63 & 1.65 & 1.51 \\
\hline 16 & trans-Linalool oxide acetate & Acyclic monoterpenoids & 1287 & 1288 & 0.13 & 0.12 & 0.13 & 0.19 \\
\hline 17 & Eugenol & Phenolic monoterpenoids & 1356 & 1358 & 12.59 & 15.98 & 16.19 & 13.16 \\
\hline 18 & $\alpha$-Copaene & Tricyclic sesquiterpenes & 1375 & 1376 & $\operatorname{tr}$ & $\operatorname{tr}$ & $\operatorname{tr}$ & $\operatorname{tr}$ \\
\hline 19 & $\beta$-Elemene & Monocyclic sesquiterpenes & 1389 & 1390 & 3.86 & 3.33 & 3.37 & 4.62 \\
\hline 20 & Methyl eugenol & Phenolic monoterpenoids & 1403 & 1403 & 0.38 & 0.40 & 0.40 & 0.53 \\
\hline 21 & $\beta$-Caryophyllene & Bicyclic sesquiterpenes & 1417 & 1419 & 0.35 & $\operatorname{tr}$ & $\operatorname{tr}$ & $\operatorname{tr}$ \\
\hline 22 & $\alpha$-trans-Bergamotene & Bicyclic sesquiterpenes & 1433 & 1434 & 4.74 & 5.70 & 5.77 & 7.56 \\
\hline 23 & $\alpha$-Guaiene & Bicyclic sesquiterpenes & 1436 & 1439 & 0.89 & 0.80 & 0.81 & 1.06 \\
\hline 24 & cis-Muurola-3,5-diene & Bicyclic sesquiterpenes & 1448 & 1450 & 0.31 & 0.30 & 0.31 & $\operatorname{tr}$ \\
\hline 25 & trans-Muurola-3,5-diene & Bicyclic sesquiterpenes & 1451 & 1452 & $\operatorname{tr}$ & $\operatorname{tr}$ & $\operatorname{tr}$ & $\operatorname{tr}$ \\
\hline 26 & Humulene ( $\alpha$-Caryophyllene) & Monocyclic sesquiterpenes & 1453 & 1454 & 0.72 & 0.61 & 0.61 & 0.86 \\
\hline 27 & trans-Muurola-4(14),5-diene & Bicyclic sesquiterpenes & 1466 & 1466 & 0.47 & 0.49 & 0.50 & 0.66 \\
\hline 28 & Germacrene D & Monocyclic sesquiterpenes & 1481 & 1481 & 4.83 & 3.93 & 3.98 & 4.23 \\
\hline 29 & Bicyclogermacrene & Bicyclic sesquiterpenes & 1500 & 1501 & 0.67 & 0.59 & 0.60 & 0.77 \\
\hline 30 & $\alpha$-Bulnesene & Bicyclic sesquiterpenes & 1509 & 1509 & 1.44 & 1.30 & 1.31 & 1.86 \\
\hline 31 & $\gamma$-Cadinene & Bicyclic sesquiterpenes & 1513 & 1513 & 2.76 & 2.91 & 2.95 & 3.58 \\
\hline 32 & $\beta$-Sesquiphellandrene & Monocyclic sesquiterpenes & 1522 & 1522 & 0.22 & 0.24 & 0.25 & 0.38 \\
\hline 33 & trans-Nerolidol & Acyclic sesquiterpenoids & 1561 & 1563 & 0.12 & $\operatorname{tr}$ & $\operatorname{tr}$ & $\operatorname{tr}$ \\
\hline 34 & 5-epi-7-epi- $\alpha$-Eudesmol & Bicyclic sesquiterpenoids & 1605 & 1607 & 1.09 & 0.75 & 0.76 & 1.21 \\
\hline 35 & 1,10-di-epi-Cubenol & Bicyclic sesquiterpenoids & 1618 & 1628 & 1.15 & 1.07 & 1.08 & 1.53 \\
\hline \multirow[t]{14}{*}{36} & epi- $\alpha$-Cadinol & Bicyclic sesquiterpenoids & 1638 & 1640 & 8.52 & 8.24 & 8.34 & 11.32 \\
\hline & & & & & \multicolumn{4}{|c|}{$\operatorname{tr} \geq 0.03$} \\
\hline & & Acyclic monoterpenes & & & 0.45 & 0.20 & 0.21 & 0.40 \\
\hline & & Acyclic monoterpenoids & & & 46.28 & 46.21 & 44.82 & 38.98 \\
\hline & & Monocyclic monoterpenes & & & 0.08 & 0.00 & 0.00 & 0.10 \\
\hline & & Monocyclic monoterpenoids & & & 2.09 & 0.57 & 0.58 & 0.57 \\
\hline & & Bicyclic monoterpenes & & & $\operatorname{tr}$ & $\operatorname{tr}$ & $\operatorname{tr}$ & $\operatorname{tr}$ \\
\hline & & Bicyclic monoterpenoids & & & 4.58 & 3.17 & 3.72 & 3.44 \\
\hline & & Phenolic monoterpenoids & & & 12.98 & 17.97 & 18.21 & 15.12 \\
\hline & & Acyclic sesquiterpenoids & & & 0.12 & $\operatorname{tr}$ & $\operatorname{tr}$ & $\operatorname{tr}$ \\
\hline & & Monocyclic sesquiterpenes & & & 9.64 & 8.10 & 8.21 & 10.09 \\
\hline & & Bicyclic sesquiterpenes & & & 11.64 & 12.08 & 12.24 & 15.50 \\
\hline & & Bicyclic sesquiterpenoids & & & 10.76 & 10.05 & 10.18 & 14.06 \\
\hline & & Tricyclic sesquiterpenes & & & $\operatorname{tr}$ & $\operatorname{tr}$ & $\operatorname{tr}$ & $\operatorname{tr}$ \\
\hline
\end{tabular}

RIcalc—calculated Kovats index; RIlit—Kovats Index by literature data [36]; tr—traces.

\section{Discussion}

The use of microbial inoculants (bacteria, fungi, mycorrhizae) in agriculture as biological control products, biofertilizers, or biostimulants is very important, taking into account their beneficial effects on plants. These include (1) growth and development promotion by improving the nutrient availability and uptake or by inducing the production of phytohormones (indole-3-acetic acid (IAA), cytokinins, gibberellins, or ethylene); (2) pathogen 
suppression by producing secondary metabolites (antibiotics, lipopeptides), by competing for nutrients and site through parasitism, or by inducing the systemic resistance (ISR); and (3) abiotic stress alleviation by producing osmoprotectants (proline, glycine betaine, exopolysaccharides etc.) $[37,38]$. Usually, one microorganism can possess more than one trait that is beneficial to plants [39]. In this study, three myco-biocontrol based products were tested for their effects on yield, physiology, production and composition of phenolic compounds and EOs in basil. Öko-ni ${ }^{\circledR}$, a product based on Coniothyrium minitans, provided the best fresh biomass yield of basil. Coniothyrium minitans is a fungus well known for its ability to suppress plant pathogens (Sclerotinia sclerotiorum) and is considered a model organism for demonstrating the influence on plant health $[38,40]$, but its direct ability on promoting the yield is not well documented. The studies where an increase in yield was observed did not focus on the growth promotion abilities of the fungus, an indirect effect of its pathogen suppression. For instance, in studies done on sunflower, celery, and lettuce, the control of wilt disease by Coniothyrium minitans was accompanied by yield increases [41].

According to the product manufacturer, the fungus produces secondary metabolites, which stimulate root growth and subsequently increase in crop yields. It is generally known that microorganisms can produce secondary metabolites such as auxins or cytokinins, which have an important role in the initiation, growth, and development of the roots. By enhancing the growth of the root systems, its exploratory capacity increase as does the availability of water and mineral nutrients that can be absorbed [42]. In this study, the observed biomass yield increase following Coniothyrium minitans (Öko-ni ${ }^{\circledR}$ ) application might be due to this mechanism. Among the cultivars applied, 'Cuisoare' responded best to Öko-ni ${ }^{\circledR}$ application; the yield increase was highest compared with the control and with the rest of the treatments. This might be because the root system of 'Cuisoare' cultivar, due to its exudates, offers a better environment for Coniothyrium minitans to grow, multiply, and survive than the rest of the cultivar tested. It is known that root exudates play a key role in the formation and survival of microorganisms' community. Studies have shown that root exudates are the most important in the formation of fungal populations [43]. Root exudates, through their composition and concentration of components, shape the underground communities [44]. For instance, the isoflavones from the exudates of soybean attract the fungal pathogen Phytophthora sojae [45], and the peroxidases and oxylipins from the exudates of the stressed tomato plants act as chemo-attractants for Trichoderma spp. [46]. In our study, taking into account that the abiotic factors and the soil type used in this experiment were the same for all the cultivars and treatments used, the root exudates of the cultivars might have played a decisive role in the multiplication and survival of Coniothyrium minitans; hence in the fresh yield, 'Cuisoare' cultivar was more suitable for the growth of fungus than the rest of the basil cultivars used.

The inoculation of microorganisms in agriculture can also influence the assimilatory pigments and the rate of photosynthesis. Previous studies demonstrated the importance of microorganisms in the physiological processes of plants. For instance, Trichoderma harzianum increased the total photosynthetic pigments in rice, Glomus spp. increased the chlorophylls in parsley, Funneliformes mosseae increased the photosynthesis rate in low moisture conditions in tomato or Trichoderma harzianum in maize $[47,48]$. In this study, the myco-bicontrol based products generally did not influence the assimilatory pigments or the photosynthesis rate, with the exception of 'Serafim' $\times$ Artis $^{\circledR}$ and 'Serafim' $\times$ Bora ${ }^{\circledR}$ interactions that increased the photosynthetic capacity.

The presence of microorganisms in soil can equally influence the growth and development of plants, but also the synthesis of specific substances such as phenolic compounds or EOs $[49,50]$. The type and the amount of phenolic compounds and EOs are important for the plant itself but also for human health, enhancing the therapeutic effect [51]. For instance, in plants, caffeic acid offers protection against pests, infections, and predators and also protects the leaves against ultraviolet radiation B. In humans, caffeic acid is known for the antibacterial, antiviral, antioxidant, anti-inflammatory, anti-cancer, anti-hepatocellular carcinoma, 
and anti-diabetic activities [52]. Hyperoside protects plants against the accumulation of reactive oxygen species [53]; in humans, it can have anti-oxidant, anti-hyperglycemic, anticancer, anti-inflammatory, or cardioprotective activities [54]. Isoquercitrin and quercitrin have shown antioxidant effects in plants and in humans against oxidative stresses, cardiovascular diseases, cancer, diabetes, anti-inflammatory disorders, or allergic reactions $[55,56]$. Rutin, known also as rutoside, protects plants against UV radiation or pathogenic attack, while in humans, rutin prevents the appearance of side effects of various treatments for cancer, diabetes, or hypercholesteremia [57]. The production of phenolic compounds in plants depends on many factors such as exposure to light, drought, wounding, nutrient stresses, or the presence of beneficial or pathogenic microorganisms [58]. Depending on the microorganism' species, the type, quality and quantity of phenolic compound can differ [59]. In our experiment, all the biocontrol products used for the 4 basil cultivars enhanced the production of phenolic compounds. Coniothyrium minitans (Öko-ni ${ }^{\circledR}$ ) stimulated to a greater extend the production of caffeic acid, Beauveria bassiana the production of quercitrin, and Arthrobotry oligospora the production of hyperoside, isoquercitrin, and rutin.

Essential oils are secondary metabolites of plants used in medicine, in the pharmaceutical and cosmetic industries, or for nutritional purposes [60]. In plants, EOs are important for the adaptation to different environmental factors, for the protection against abiotic and biotic stresses or for signaling among plants [61]. The presence of microorganisms in soil can influence the production of EO, its quality, quantity and composition. For instance, an arbuscular mycorrhizal fungus (Glomus mosseae) significantly increased the EO content in two oregano genotypes, and the inoculation of sweet basil with the plant growth-promoting bacteria Bacillus subtilis GB03 increased the accumulation of two EO components (R-terpineol and eugenol) [62,63]. In this experiment, increases in the EO content were registered for all the treatments applied, with the highest increases observed in basil plants treated with Öko-ni ${ }^{\circledR}$ (Coniothyrium minitans) and Bora ${ }^{\circledR}$ (Beauveria bassiana). Even though 'Cuisoare' cultivar treated with Öko-ni ${ }^{\circledR}$ registered the highest fresh yield, the EO content was not the best. The EO content was highest in cv. 'Macedon' in the presence of Beauveria bassiana and Coniothyrium minitans. As expected, in this study, the EO composition depended on the cultivar and treatment applied. The application of biocontrol products stimulated the synthesis of the main compounds. For example, the linalool concentration increased in 'Aromat de Buzau' by $15 \%$ in Artis $^{\circledR}, 24 \%$ in Bora ${ }^{\circledR}$, and $10 \%$ in Öko-ni ${ }^{\circledR}$. Linalool is an acyclic monoterpene also found in plants such as lavender and is used in perfumery and hygiene products such as soap and detergent [64]. In 'Serafim' and 'Cuisoare', the linalool content increased only with Artis ${ }^{\circledR}$ treatment. Moreover, for these cultivars, the eugenol content increased by up to $19 \%$ in 'Serafim' in the Öko-ni ${ }^{\circledR}$ variant and up to $28 \%$ in 'Cuisoare' in the Bora ${ }^{\circledR}$ variant. Eugenol belongs to the class of phenylpropanoids and is the main constituent of the EO of cloves (Syzygium aromaticum). Due to its antioxidant and anti-inflammatory properties, eugenol is used in the cosmetics industry but also in the food industry as a preservative [65]. The application of Öko-ni ${ }^{\circledR}$ increased the concentrations of neural and geranium by $25 \%$ and $27 \%$ in cv. 'Macedon'. The two compounds constitute the cis (neral) and trans (geranial) form of citral, which belongs to the class of terpenoids and has the scent of lemon. It is found in many other plants such as lemongrass and ginger and has antifungal, antibacterial, anti-inflammatory, and anti-cancer activities. It is used as a spice, as flavoring in cosmetics, and as raw material in the synthesis of medicinal compounds such as vitamin A, ionone, and methyloneone [66]. This study confirms the fact that the microorganism species and plant cultivar can influence the EO content and its composition [35].

\section{Conclusions}

In this study, three biocontrol formulates were tested to evaluate their effect on the yield, physiology, and synthesis of phenolic compounds, as well as EO in four varieties of basil cultivated in the ecological system. All treatments increased crop yields relative to the non-treated control. From a physiological point of view, a higher content of assimilat- 
ing pigments was recorded in 'Serafim' probably due to the contribution of anthocyanin pigments. Increases of up to $2 \%$ in chlorophyll content and up to $66 \%$ in the rate of photosynthesis have been reported with Beauveria bassiana $\left(\right.$ Bora $\left.^{\circledR}\right)$. Oil production increased significantly with all treatments, up to $34 \%$ (Bora ${ }^{\circledR}$ and Öko-ni ${ }^{\circledR}$ ). The treatments applied stimulated the synthesis of phenolic compounds; thus, the content of caffeic acid was higher in Öko-ni ${ }^{\circledR}$, and the content of hyperoside, isoquercitrin, and rutin was higher under the treatment with Arthrobotrys oligospora $\left(\right.$ Artis $\left.^{\circledR}\right)$, while the quercitrin content was higher in Bora ${ }^{\circledR}$. The main compounds found in the EOs were linalool and methyl chavicol in 'Aromat de Buzau', linalool and eugenol in 'Serafim', neral and geranial in 'Macedon', and linalool and eugenol in 'Cuisoare'. Overall, the investigated myco-biocontrol formulates had positive effects on basil crop, stimulating both the fresh biomass yields, as well as the accumulation of the EO and phenolic compounds.

Author Contributions: Conceptualization, G.-C.T., V.S. and N.M.; methodology, G.-C.T., I.D., I.B., A.C. and L.-D.P.; software, M.B.; validation, I.D.; formal analysis, I.D., I.B., G.-C.T., A.C. and L.-D.P.; investigation, G.-C.T., A.C., L.-D.P., I.D. and I.B.; resources, V.S., N.M., V.D.Z. and I.D.; data curation, V.D.Z., M.B. and G.M.; writing-original draft preparation, G.-C.T.; writing-review and editing, M.B., G.M. and V.D.Z.; visualization, G.-C.T.; supervision, V.S.; project administration, G.-C.T. All authors are principal authors and have equal rights. All authors have read and agreed to the published version of the manuscript.

Funding: The authors acknowledge the in-kind and cash support by the "Ion Ionescu de la Brad" University of Agricultural Sciences and Veterinary Medicine of Iasi, Romania.

Institutional Review Board Statement: Not applicable.

Informed Consent Statement: Not applicable.

Data Availability Statement: The data presented in this study are available within the article.

Acknowledgments: We thank Bireescu Gianina from the Institute of Biological Research (Iasi) for providing the myco-biocontrol products.

Conflicts of Interest: The authors declare no conflict of interest.

\section{References}

1. Bączek, K.; Kosakowska, O.; Gniewosz, M.; Gientka, I.; Węglarz, Z. Sweet Basil (Ocimum basilicum L.) Productivity and raw material quality from organic cultivation. Agronomy 2019, 9, 279. [CrossRef]

2. Zheljazkov, V.D.; Callahan, A.; Cantrell, C.L. Yield and oil composition of 38 basil (Ocimum basilicum L.) accessions grown in Mississippi. J. Agric. Food Chem. 2008, 56, 241-245. [CrossRef] [PubMed]

3. De la Portilla, N.; Vaca, R.; Mora-Herrera, M.E.; Salinas, L.; Del Aguila, P.; Yañez-Ocampo, G.; Lugo, J. Soil amendment with biosolids and inorganic fertilizers: Effects on biochemical properties and oxidative stress in basil (Ocimum basilicum L.). Agronomy 2020, 10, 1117. [CrossRef]

4. Prinsi, B.; Morgutti, S.; Negrini, N.; Faoro, F.; Espen, L. Insight into composition of bioactive phenolic compounds in leaves and flowers of green and purple basil. Plants 2020, 9, 22. [CrossRef]

5. Burducea, M.; Lobiuc, A.; Asandulesa, M.; Zaltariov, M.-F.; Burducea, I.; Popescu, S.M.; Zheljazkov, V.D. Effects of sewage sludge amendments on the growth and physiology of sweet basil. Agronomy 2019, 9, 548. [CrossRef]

6. Ciriello, M.; Pannico, A.; El-Nakhel, C.; Formisano, L.; Cristofano, F.; Duri, L.G.; Pizzolongo, F.; Romano, R.; De Pascale, S.; Colla, G.; et al. Sweet Basil Functional Quality as Shaped by Genotype and Macronutrient Concentration Reciprocal Action. Plants 2020, 9, 1786. [CrossRef] [PubMed]

7. Ciriello, M.; Formisano, L.; El-Nakhel, C.; Kyriacou, M.C.; Soteriou, G.A.; Pizzolongo, F.; Romano, R.; De Pascale, S.; Rouphael, Y. Genotype and Successive Harvests Interaction Affects Phenolic Acids and Aroma Profile of Genovese Basil for Pesto Sauce Production. Foods 2021, 10, 278. [CrossRef] [PubMed]

8. Cruz, L.R.O.; Fernandes, Â.; Di Gioia, F.; Petropoulos, S.A.; Polyzos, N.; Dias, M.I.; Pinela, J.; Kostić, M.; Soković, M.D.; Ferreira, I.C.F.R.; et al. The Effect of Nitrogen Input on Chemical Profile and Bioactive Properties of Green- and Red-Colored Basil Cultivars. Antioxidants 2020, 9, 1036. [CrossRef]

9. Eurostat, Organic Farming Statistics. Available online: https://ec.europa.eu/eurostat/statistcs-ecplained/index.php/organic farming_statistics (accessed on 22 December 2020).

10. Organic Trade Association. 2020. Available online: https:/ / ota.com/news/press-releases/21328 (accessed on 19 December 2020).

11. Merot, A.; Fermaud, M.; Gosme, M.; Smits, N. Effect of conversion to organic farming on pest and disease control in French vineyards. Agronomy 2020, 10, 1047. [CrossRef] 
12. Murariu, O.C.; Robu, T.; Ișan, E.; Irimia, L.; Murariu, F. Researches regarding pesticides and it's metabolites dynamics in fruit in 2014 year marked in Romania and assessment of human health risks. J. Biotechnol. 2019, 305, s68-s69. [CrossRef]

13. Murariu, F.; Voda, A.D.; Murariu, O.C. Researches on food safety assessment-Supporting a healthy lifestyle for the population from NE of Romania. J. Biotechnol. 2019, 305, s68. [CrossRef]

14. Butu, M.; Stef, R.; Corneanu, M.; Butnariu, M. Mycoremediation: A Sustainable Approach for Pesticide Pollution Abatement. In Bioremediation and Biotechnology; Bhat, R., Hakeem, K., Dervash, M., Eds.; Springer: Cham, Switerland, 2020; Volume 2. [CrossRef]

15. Butu, A.; Grozea, I.; Sarac, I.; Butnariu, M. Global Scenario of Remediation Techniques to Combat Pesticide Pollution. In Bioremediation and Biotechnology; Bhat, R., Hakeem, K., Dervash, M., Eds.; Springer: Cham, Switerland, 2020; Volume 2. [CrossRef]

16. Murariu, O.C.; Isan, E.; Robu, T.; Irimia, L.M.; Dicu, L.; Ratu, R.N.; Murariu, F. Evaluation of the Presence of the Pesticide Residues and It's Metabolites from Raw Materials Used as Sources for Ensuring a Healthy Nutrition for Athletes. In The Impact of Sport and Physical Education Science on Today's Society; Hodorca, R.M., Onose, I., Eds.; Proceedings of I.C.U.; 2018; pp. 185-191. Available online: http:/ / www.edlearning.it/ebook/BY23.pdf (accessed on 22 December 2020).

17. Vodă, A.D.; Robu, T.; Robu, D.; Murariu, F.; Murariu, O.C. 2019-Residues of pesticides and it's metabolites from vegetal products. J. Biotechnol. 2019, 305, s69. [CrossRef]

18. COM (2020) 381. Available online: https:/ / eur-lex.europa.eu/legal-content/EN/TXT/?uri=CELEX:52020DC0381 (accessed on 18 January 2021).

19. Inglis, G.D.; Goettel, M.S.; Johnson, D.L. Influence of ultraviolet light protectants on persistence of the entomopathogenic fungus, Beauveria bassiana. Biol. Control 1995, 5, 581-590. [CrossRef]

20. Mittal, N.; Saxena, G.; Mukerji, K.G. Biological control of root-knot nematode by nematode-destroying fungi. In From Ethnomycology to Fungal Biotechnology; Singh, J., Aneja, K.R., Eds.; Springer: Boston, MA, USA, 1999; Available online: https: / / doi.org/10.1007/978-1-4615-4815-7_15 (accessed on 22 December 2020).

21. Vega, F.E.; Goettel, M.S.; Blackwell, M.; Chandler, D.; Jackson, M.A.; Keller, S.; Koike, M.; Maniania, N.K.; Monzon, A.; Ownley, B.H.; et al. Fungal entomopathogens: New insights on their ecology. Fungal Ecol. 2009, 2, 149-159. [CrossRef]

22. Amobonye, A.; Bhagwat, P.; Pandey, A.; Singh, S.; Pillai, S. Biotechnological potential of Beauveria bassiana as a source of novel biocatalysts and metabolites. Crit. Rev. Biotechnol. 2020, 40, 1019-1034. [CrossRef] [PubMed]

23. De Faria, M.R.; Wright, S.P. Mycoinsecticides and mycoacaricides: A comprehensive list with worldwide coverage and international classification of formulation types. Biol. Control 2007, 43, 237-256. [CrossRef]

24. Zafar, J.; Shoukat, R.F.; Zhang, Y.; Freed, S.; Xu, X.; Jin, F. Metarhizium anisopliae challenges immunity and demography of Plutella xylostella. Insects 2020, 11, 694. [CrossRef]

25. Ugine, T.A.; Wraight, S.P.; Sanderson, J.P. Effects of manipulating spray-application parameters on efficacy of the entomopathogenic fungus Beauveria bassiana against western flower thrips, Frankliniella occidentalis, infesting greenhouse impatiens crops. Biocontrol Sci. Technol. 2007, 17, 193-219. [CrossRef]

26. Jacobson, R.; Chandler, D.; Fenlon, J.; Russell, K. Compatibility of Beauveria bassiana (Balsamo) Vuillemin with Amblyseius cucumeris Oudemans (Acarina: Phytoseiidae) to control Frankliniella occidentalis Pergande (Thysanoptera: Thripidae) on cucumber plants. Biocontrol Sci. Technol. 2001, 11, 391-400. [CrossRef]

27. Ansari, M.; Brownbridge, M.; Shah, F.; Butt, T. Efficacy of entomopathogenic fungi against soil-dwelling life stages of western flower thrips, Frankliniella occidentalis, in plant-growing media. Entomol. Exp. Appl. 2008, 127, 80-87. [CrossRef]

28. Prova, A.; Akanda, A.M.; Islam, S.; Hossain, M.M. Characterization of Sclerotinia sclerotiorum, an emerging fungal pathogen causing blight in Hyacinth Bean (Lablab purpureus). Plant Pathol. J. 2018, 34, 367-380. [CrossRef] [PubMed]

29. Whipps, J.M.; Sreenivasaprasad, S.; Muthumeenakshi, S.; Rogers, C.W.; Challen, M.P. Use of Coniothyrium minitansas a biocontrol agent and some molecular aspects of sclerotial mycoparasitism. Eur. J. Plant Pathol. 2008, 121, 323-330. [CrossRef]

30. Behie, S.W.; Zelisko, P.; Bidochka, M.J. Endophytic insect-parasitic fungi translocate nitrogen directly from insects to plants. Science 2012, 336, 1576-1577. [CrossRef] [PubMed]

31. Sood, M.; Kapoor, D.; Kumar, V.; Sheteiwy, M.S.; Ramakrishnan, M.; Landi, M.; Araniti, F.; Sharma, A. Trichoderma: The "Secrets" of a multitalented biocontrol agent. Plants 2020, 9, 762. [CrossRef] [PubMed]

32. Doni, F.; Isahak, A.; Zain, C.R.C.M.; Ariffin, S.M.; Mohamad, W.N.W.; Yusoff, W.M.W. Formulation of Trichoderma sp. SL2 inoculants using different carriers for soil treatment in rice seedling growth. Springerplus 2014, 3, 532. [CrossRef] [PubMed]

33. Shukla, N.; Awasthi, R.P.; Rawat, L.; Kumar, J. Biochemical and physiological responses of rice (Oryza sativa L.) as influenced by Trichoderma harzianum under drought stress. Plant Physiol. Biochem. 2012, 54, 78-88. [CrossRef] [PubMed]

34. Vlase, L.; Parvu, M.; Parvu, E.A. Chemical constituents of three Allium species from Romania. Molecules 2013, 18, 114-127. [CrossRef] [PubMed]

35. Burducea, M.; Zheljazkov, V.D.; Dincheva, I.; Lobiuc, A.; Teliban, G.C.; Stoleru, V.; Zamfirache, M.M. Fertilization modifies the essential oil and physiology of basil varieties. Ind. Crop Prod. 2018, 121, 282-293. [CrossRef]

36. Adams, R.P. Identification of Essential Oil Components by Gas Chromatography/Mass Spectrometry, 4th ed.; Allured Publ.: Carol Stream, IL, USA, 2007.

37. Grover, M.; Ali, S.Z.; Sandhya, V.; Rasul, A.; Venkateswarlu, B. Role of microorganisms in adaptation of agriculture crops to abiotic stresses. World J. Microbiol. Biotechnol. 2011, 27, 1231-1240. [CrossRef]

38. Berg, G. Plant-microbe interactions promoting plant growth and health: Perspectives for controlled use of microorganisms in agriculture. Appl. Microbiol. Biotechnol. 2009, 84, 11-18. [CrossRef] [PubMed] 
39. Olanrewaju, O.S.; Glick, B.R.; Babalola, O.O. Mechanisms of action of plant growth promoting bacteria. World J. Microbiol. Biotechnol. 2017, 33, 197. [CrossRef]

40. Tabassum, B.; Khan, A.; Tariq, M.; Ramzan, M.; Khan, M.S.I.; Shahid, N.; Aaliya, K. Bottlenecks in commercialisation and future prospects of PGPR. Appl. Soil Ecol. 2017, 121, 102-117. [CrossRef]

41. Whipps, J.M.; Gerlagh, M. Biology of Coniothyrium minitans and its potential for use in disease biocontrol. Mycol. Res. 1992, 96, 897-907. [CrossRef]

42. Ortíz-Castro, R.; Contreras-Cornejo, H.A.; Macías-Rodríguez, L.; López-Bucio, J. The role of microbial signals in plant growth and development. Plant Signal. Behav. 2009, 4, 701-712. [CrossRef] [PubMed]

43. Berg, G.; Smalla, K. Plant species and soil type cooperatively shape the structure and function of microbial communities in the rhizosphere. FEMS Microbiol. Ecol. 2009, 68, 1-13. [CrossRef] [PubMed]

44. Haichar, F.E.; Santaella, C.; Heulin, T.; Achouak, W. Root exudates mediated interactions belowground. Soil Biol. Biochem. 2014, 77, 69-80. [CrossRef]

45. Morris, P.F.; Bone, E.; Tyler, B.M. Chemotropic and contact responses of Phytophthora sojae hyphae to soybean isoflavonoids and artificial substrates. Plant Physiol. 1998, 117, 1171-1178. [CrossRef]

46. Lombardi, N.; Vitale, S.; Turra, D.; Reverberi, M.; Fanelli, C.; Vinale, F.; Marra, R.; Ruocco, M.; Pascale, A.; d’Errico, G.; et al. Root exudates of stressed plants stimulate and attract Trichoderma soil fungi. Mol. Plant Microbe Interact. 2018, 31, 982-994. [CrossRef] [PubMed]

47. Szczałba, M.; Kopta, T.; Gazstoł, M.; Sezkara, A. Comprehensive insight into arbuscular mycorrhizal fungi, Trichoderma spp. and plant multilevel interactions with emphasis on biostimulation of horticultural crops. J. Appl. Microbiol. 2019, 127, 630-647. [CrossRef] [PubMed]

48. Abdel-Fattah, G.M.; Shabana, Y.M.; Ismail, Y.M.; Rashad, Y.M. Trichoderma harzianum: A biocontrol agent against Bipolaris oryzae. Mycopathologia 2007, 164, 81-89. [CrossRef] [PubMed]

49. Teliban, G.C.; Stoleru, V.; Burducea, M.; Lobiuc, A.; Munteanu, N.; Popa, L.D.; Caruso, G. Biochemical, physiological and yield characteristics of red basil as affected by cultivar and fertilization. Agriculture 2020, 10, 48. [CrossRef]

50. Golubkina, N.; Logvinenko, L.; Novitsky, M.; Zamana, S.; Sokolov, S.; Molchanova, A.; Shevchuk, O.; Sekara, A.; Tallarita, A.; Caruso, G. Yield, Essential Oil and Quality Performances of Artemisia dracunculus, Hyssopus officinalis and Lavandula angustifolia as Affected by Arbuscular Mycorrhizal Fungi under Organic Management. Plants 2020, 9, 375. [CrossRef] [PubMed]

51. Onofrei, V.; Benchennouf, A.; Jancheva, M.; Loupassaki, S.; Ouaret, W.; Burducea, M.; Lobiuc, A.; Teliban, G.C.; Robu, T. Ecological foliar fertilization effects on essential oil composition of sweet basil (Ocimum basilicum L.) cultivated in a field system. Sci. Hortic. 2018, 239, 104-113. [CrossRef]

52. Espíndola, K.M.M.; Ferreira, R.G.; Narvaez, L.E.M.; Rosario, A.C.R.S.; da Silva, A.H.M.; Silva, A.G.B.; Vieira, A.P.O.; Monteiro, M.C. Chemical and pharmacological aspects of caffeic acid and its activity in hepatocarcinoma. Front. Oncol. $2019,9,541$. [CrossRef]

53. Chen, Y.H.; Zhang, X.R.; Guo, Q.S.; Cao, L.P.; Qin, Q.; Li, C.; Zhao, M.; Wang, W.M. Plant morphology, physiological characteristics, accumulation of secondary metabolites and antioxidant activities of Prunella vulgaris L. under UV solar exclusion. Biol. Res. 2019, 52, 17. [CrossRef] [PubMed]

54. Ku, S.K.; Zhou, W.; Lee, W.; Han, M.S.; Na, M.; Bae, J.S. Anti-inflammatory effects of hyperoside in human endothelial cells and in mice. Inflammation 2015, 38, 784-799. [CrossRef]

55. Valentová, K.; Vrba, J.; Bancírová, M.; Ulrichová, J.; Kren, V. Isoquercitrin: Pharmacology, toxicology, and metabolism. Food Chem. Toxicol. 2014, 68, 267-282. [CrossRef]

56. Kurepa, J.; Shull, T.E.; Smalle, J.A. Quercetin feeding protects plants against oxidative stress. F1000Research 2016, 5, 2430. [CrossRef]

57. Kianersi, F.; Abdollahi, M.R.; Mirzaie-asl, A.; Dastan, D.; Rasheed, F. Identification and tissue-specific expression of rutin biosynthetic pathway genes in Capparis spinosa elicited with salicylic acid and methyl jasmonate. Sci. Rep. 2020, 10, 8884. [CrossRef]

58. Bhattacharya, A.; Sood, P.; Citovsky, V. The roles of plant phenolics in defense and communication during Agrobacterium and Rhizobium infection. Mol. Plant Pathol. 2010, 11, 705-719. [CrossRef] [PubMed]

59. Mandal, S.M.; Chakraborty, D.; Dey, S. Phenolic acids act as signaling molecules in plant-microbe symbioses. Plant Signal. Behav. 2010, 5, 359-368. [CrossRef] [PubMed]

60. Sharifi-Rad, J.; Sureda, A.; Tenore, G.C.; Daglia, M.; Sharifi-Rad, M.; Valussi, M.; Tundis, R.; Sharifi-Rad, M.; Loizzo, M.R.; Ademiluyi, A.O.; et al. Biological activities of essential oils: From plant chemoecology to traditional healing systems. Molecules 2017, 22, 70. [CrossRef]

61. Boaro, C.S.F.; Vieira, M.A.R.; Campos, F.G.; Ferreira, G.; De-la-Cruz-Chacón, I.; Marques, M.O.M. Factors influencing the production and chemical composition of essential oils in aromatic plants from Brazil. In Essential Oil Research; Malik, S., Ed.; Springer: Cham, Switerland, 2019; pp. 19-47.

62. Banchio, E.; Bogino, P.C.; Zygadlo, J.; Giordano, W. Plant growth promoting rhizobacteria improve growth and essential oil yield in Origanum majorana L. Biochem. Syst. Ecol. 2008, 36, 766-771. [CrossRef]

63. Banchio, E.; Xie, X.; Zhang, H.; Pare, P.W. Soil bacteria elevate essential oil accumulation and emissions in sweet basil. J. Agric. Food Chem. 2009, 57, 653-657. [CrossRef] 
64. Milanos, S.; Elsharif, S.A.; Janzen, D.; Buettner, A.; Villmann, C. Metabolic products of linalool and modulation of GABAA receptors. Front. Chem. 2017, 5, 46. [CrossRef] [PubMed]

65. Barboza, I.N.; Bezerra, C.D.M.; Silva, R.O.; Medeiros, J.V.R.; de Sousa, D.P. An overview on the anti-inflammatory potential and antioxidant profile of eugenol. Oxidative Med. Cell. Longev. 2018, 2018, 3957262. [CrossRef]

66. Liao, P.C.; Yang, T.S.; Chou, J.C.; Chen, J.; Lee, S.C.; Kuo, Y.H.; Ho, C.L.; Chao, L.K.P. Anti-inflammatory activity of neral and geranial isolated from fruits of Litsea cubeba Lour. J. Funct. Foods 2015, 19, 248-258. [CrossRef] 